\title{
Vaginal hysterectomy in non-prolapsed uteruses: 6-year experience
}

\author{
Histerectomia vaginal em útero sem prolapso - experiência de 6 anos
}

\author{
Thomaz Rafael Gollop ${ }^{1}$, Adriana Grandesso dos Santos ${ }^{2}$, Alexandre Guilherme Zabeu Rossi², \\ Rogério Francisco Bianchi ${ }^{2}$
}

\begin{abstract}
Objective: To evaluate the applicability of the technique of vaginal hysterectomy in non-prolapsed uterus. Methods: A retrospective cohort study with 220 patients submitted to vaginal hysterectomy from January 2004 to July 2010 by the Vaginal Surgery and Pelvic Floor Team. Patients mean age was 44.4 years and they had on average three births (0-10 deliveries). The surgery was performed even in cases of previous abdominal surgery, and cesarean section was prevalent in $54.6 \%$ of patients. Results: The mean uterus weight was $278.9 \mathrm{~g}$. The mean operative time was 93 minutes, and length of hospital stay was 24 hours after surgery in $65 \%$ of cases. There were no cases of visceral injury. The mean postoperative complication was cellulitis of the vaginal vault that occurred in 11 cases $(5 \%)$ that received antibiotics. Mean blood loss corresponded to $1.4 \mathrm{~g} / \mathrm{dL}$ hemoglobin. From the analyzed sample, vaginal hysterectomy by vaginal route was feasible in $96.8 \%$ of patients, and abdominal conversion was necessary in $3.2 \%$. Conclusion: Vaginal hysterectomy is a minimally invasive surgery, with fewer complications, and low morbidity. We believe that this procedure should be indicated to treat gynecological benign diseases.
\end{abstract}

Keywords: Hysterectomy/methods; Surgical procedures, minimally invasive; Hysterectomy, vaginal; Uterine prolapse

\section{RESUMO}

Objetivo: Avaliar a aplicabilidade da técnica de histerectomia vaginal em úteros sem prolapso. Métodos: Estudo de coorte retrospectivo de 220 pacientes submetidas à histerectomia vaginal no período de janeiro de 2004 a julho de 2010, pela Equipe de Cirurgia Vaginal e do Assoalho Pélvico. A média de idade dos pacientes foi de 44,4 anos e tiveram, em média, 3 partos (0-10 partos). A cirurgia foi realizada mesmo em casos de cirurgias abdominais prévias; a cesárea foi prevalente em $54,6 \%$ da amostra. Resultados: 0 peso médio do útero foi de $278,9 \mathrm{~g}$. 0 tempo cirúrgico médio foi de 93 minutos, e o tempo de internação foi de 24 horas pós-operatórias em $65 \%$ dos casos. Não houve nenhum caso de lesão visceral. A complicação pós-operatória mais frequente foi celulite de cúpula, que ocorreu em 11 casos (5\%), sendo tratadas com antibioticoterapia. A perda sanguínea foi, em média, de 1,4g/dL de hemoglobina. Foi possível a realização da histerectomia pela via vaginal em $96,8 \%$ das pacientes da amostra estudada e em 3,2\% foi necessária a conversão para via abdominal. Conclusão: A histerectomia vaginal é uma cirurgia por orifício natural, minimamente invasiva, com baixas frequência de complicações e morbidade, sendo factível e segura para o tratamento de afecções uterinas benignas.

Descritores: Histerectomia/métodos; Procedimentos cirúrgicos minimamente invasivos; Histerectomia vaginal; Prolapso uterino

\section{INTRODUCTION}

Hysterectomy is the most common gynecologic surgery performed worldwide. In the United States a mean of 600 thousand hysterectomies are done yearly ${ }^{(1,2)}$. Routes of hysterectomy are: abdominal, vaginal, laparoscopic and robotic. It is possible to use two routes associated with vaginal hysterectomy ( $\mathrm{VH}$ ) assisted by a laparoscopic procedure.

The vaginal laparoscopy and the robotic route are considered minimally invasive techniques particularly to be associated with lesser pain in the postoperative period, shorter length of hospital stay and better patient recovery when compared with the abdominal route ${ }^{(3)}$.

$\mathrm{VH}$, which is performed through a natural orifice, has the advantage of no visible scars and the use of permanent surgical material that reduces costs when

\footnotetext{
Study carried out at Vaginal Surgery and Pelvic Floor Group of Women's Health Reference Center at Hospital Pérola Byington - São Paulo (SP), Brazil.

${ }^{1}$ Hospital Israelita Albert Einstein - HIAE, São Paulo (SP), Brazil.

${ }^{2}$ Hospital Albert Einstein - HIAE, São Paulo (SP), Brazil; Hospital Pérola Byington - São Paulo (SP), Brazil.

Corresponding author: Thomaz Rafael Gollop - Avenida Albert Einstein, 627/701 - Office \#118 - 1st floor - Building A1 - Morumbi - Zip code: $05651-901$ - São Paulo (SP), Brazil - E-mail: trgollop@usp.br

Received on: 8/12/2011 - Accepted on: 22/11/2012

Conflicts of interest: none.
} 
compared to laparoscopy and robotic technique ${ }^{(4)}$. Despite the advantages of $\mathrm{VH}$ the abdominal hysterectomy is the most used technique worldwide. For example, in the United States in 2003 the number of procedures by the abdominal route reached $66.1 \%$. Surprisingly, in the same year, VH was used only in $21.8 \%$ of patients and the laparoscopic hysterectomy in $11.8 \%{ }^{(2)}$.

Although prolapsed uterus constitutes the most common reason for $\mathrm{VH}$, its use should not be limited to the surgery of pelvic floor reconstruction. $\mathrm{VH}$ has benefits also in the treatment of myomas and abnormal uterine bleeding, which are usually the indications to hysterectomy ${ }^{(5)}$. The vaginal route is less used in Brazil for such indications, which justifies the report of our experience using $\mathrm{VH}$ in the absence of prolapsed uteruses.

\section{OBJECTIVE}

To evaluate the applicability of $\mathrm{VH}$ in non-prolapsed uteruses.

\section{METHODS}

This was a retrospective cohort study describing the results of a six years experience (January 2004 to July 2010) in performing VH by the Vaginal Surgery and Pelvic Floor Team of Hospital Pérola Byington in São Paulo (SP), Brazil. This study was approved by the Ethical and Research Committee of the same hospital (protocol \# 049/11).

A total of 220 patients were submitted to $\mathrm{VH}$ performed by the Heaney technique ${ }^{(6)}$. Data was collected regarding pre-operatory diagnoses, age, parity, body mass index (BMI, data by weight $\mathrm{kg} /$ height $^{2}$ ), duration of surgery, intra and post-operative complications and length of hospital stay.

Patients were clinically examined to verify those who were elected for the vaginal route considering the following criteria: vaginal permeability of at least $4 \mathrm{~cm}$, mobile uterus with fundus reaching at most the umbilical scar, fundus of the vaginal sac large and free $(>3 \mathrm{~cm})$, and the absence of a prolapsed uterus. Preoperative laboratorial tests, oncotic colpocytology and one transvaginal pelvic ultrasonography were done. Patients signed the consent form before being submitted to the surgery.

The pre-operative data are described on table 1 . Patients median age was 44 years ( 32 to 75 years). The median parity was three (zero to ten deliveries). Distribution of parity is shown on figure 1: 12 were nulliparous (5.4\%), 88 patients had only vaginal delivery (40\%), 60 had only cesarean section $(27.3 \%)$ and 60 had both vaginal and cesarean section delivery. Of the 220 patients, $120(54.6 \%)$ had at least one cesarean section, and 56 of them $(25.4 \%)$ had two or more cesarean sections.

The BMI was $29.2 \mathrm{~kg} / \mathrm{m}^{2}\left(18.9\right.$ a $\left.64.2 \mathrm{~kg} / \mathrm{m}^{2}\right)$. Eight patients had $\mathrm{BMI}>40(3.6 \%)$.

Table 1. Pre-operative data

\begin{tabular}{lc}
\hline Pre-operative data & n (median) \\
\hline Age & $44(32-75)$ \\
Parity & $3(0-10)$ \\
BMl & $29(18-64)$ \\
\hline
\end{tabular}

BMI: body mass index.

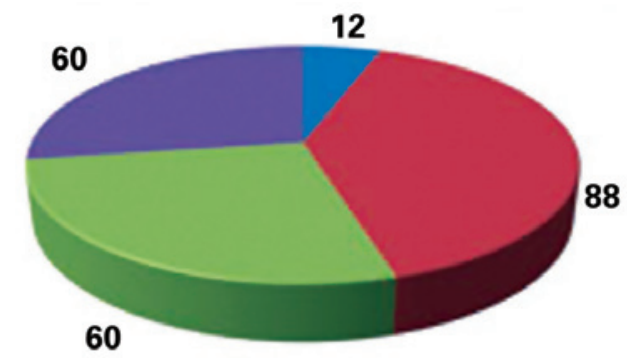

Nulliparous women $(5.4 \%)$,

Only vaginal delivery $(40 \%)$,

Only cesarean section (27.3\%)

Both vaginal and cesarean section delivery $(27.3 \%)$

Figure 1. Parity distribution

Surgical indications are described in table 2: 217 patients had metrorrhagia and/or uterine miomatosis, 2 had cervical intraepithelial neoplasia grade 2 (NIC 2) and 1 patient had complex endometrial hyperplasia without atypias and obesity $\left(\mathrm{BMI}=64.2 \mathrm{~kg} / \mathrm{m}^{2}\right)$. In only three cases $(1.4 \%)$ surgery was not indicated due to metrorrhagia and/or uterine miomatosis

Table 2. Surgical indications

\begin{tabular}{lc}
\hline Surgical indications & $\mathbf{n}(\%)$ \\
\hline Miomatosis/metrorrhagia & $217(98.6)$ \\
Cervical dysplasia & $2(0.9)$ \\
Endometrial hyperplasia & $1(0.5)$ \\
\hline
\end{tabular}




\section{RESULTS}

The intra-operative data are shown on table 3. Surgeries had a mean duration of 93 minutes (30 to 200 minutes). The mean uterine weight was $278.9 \mathrm{~g}$ ( $72 \mathrm{to} 950 \mathrm{~g}$ ). A total of 96 patients were submitted to bilateral salpingectomy in order to prevent ovarian cancer and hydrosalpinx, and 21 patients underwent a transobturator sling procedure to correct urinary incontinence.

Table 3. Intra-operative data

\begin{tabular}{lc}
\hline Intra-operative data & Results \\
\hline Duration of surgery (min.) & $93(30-200)$ \\
$\Delta \mathrm{Hb}^{*}(\mathrm{~g} / \mathrm{dL})$ in 12 hours & $1.4(0-5.1)$ \\
$\Delta \mathrm{Hb}(\mathrm{g} / \mathrm{dL})>4$ & $3(1.4 \%)$ \\
Transfusion & $8(3.6 \%)$ \\
Uterine weight $(\mathrm{g})$ & $278.9(72-950)$ \\
Urinary/intestinal lesion & 0 \\
HTA Converter & $7(3.2 \%)$ \\
\hline
\end{tabular}

min: minutes; $\triangle \mathrm{Hb}$ : hemoglobin variation

Blood loss was estimated using the hemoglobin variation rate on anesthesia time, and then repeated 12 hours after the surgery. The mean blood loss corresponded to $1.4 \mathrm{~g} / \mathrm{dL}$ ( 0 to $-5.1 \mathrm{~g} / \mathrm{dL})$. In three cases a variation of more than $4 \mathrm{~g} / \mathrm{dL}$ was noted, accounting for $1.4 \%$ of cases. Eight patients received blood transfusion intraoperatively (3.6\%), among these patients four had anemia before surgery, and four had bleeding during the procedure. The mean uterine weight of these eight patients was 508.6g and, two had abdominal conversion because the surgery did not progress by the vaginal route.

In the end, seven patients were submitted to abdominal hysterectomy. Among these patients the mean uterine weight was $618.2 \mathrm{~g}$ (450 to $683 \mathrm{~g}$ ). This mean was above the total mean in this study that was $278.9 \mathrm{~g}$ ( 72 to $950 \mathrm{~g})$.

The post-operative data can be seen on table 4. No vesical or intestinal lesion was seen. In the first day after surgery $65 \%$ of patients were discharged, in the second day $30 \%$, and in the third day or later $5 \%$.

In two cases pelvic abscesses were seen $(0.9 \%)$ and patients were reoperated, 11 cases had vaginal vault cellulitis $(5 \%)$ being treated with antibiotics. Four patients were rehospitalized for clinical treatment $(1.8 \%)$. A total of 20 cases $(9.1 \%)$ had little complications like vaginal vault granulomata, which were cauterized.
Table 4. Post-operative data

\begin{tabular}{lc}
\hline Post-operative data & n (\%) \\
\hline P01 discharge & $143(65)$ \\
P02 discharge & $66(30)$ \\
Dicharge after $>48$ hours & $11(5)$ \\
Pelvic abscess & $2(0.9)$ \\
Vaginal vault cellulitis & $11(5)$ \\
Clinical rehospitalization & $4(1.8)$ \\
Vaginal vault granulomata & $20(9.1)$ \\
\hline
\end{tabular}

PO: post-operative

\section{DISCUSSION}

$\mathrm{VH}$ is a minimally invasive surgery performed through a natural orifice that presents fewer complications, low morbidity and no visible scar. Some reasons or criteria used to contraindicate the VH such as "no prolapse", "the uterus is too large", "history of previous abdominal surgery", "patients did not have vaginal delivery" and "oophorectomy is required" were not effective in the patients of this $\operatorname{study}^{(7)}$.

One limitation of this study is that the results refer to data obtained in a six years experience including the learning curve process. Over the years, data as duration of surgery, intraoperative bleeding and need of abdominal conversion are decreasing. Besides, because this surgery is acknowledged for a long time in gynecology, few recent studies comparing different the techniques' efficiency are found in the literature.

In 2004 a study was published by Paparella et al. involving 204 patients submitted to $\mathrm{VH}$, with of two year follow-up. They evaluated applicability and complication index when the surgery was performed in cases of slightly enlarged uterus, nulliparous women and/or patients who had previous cesarean sections. Patients with prolapsed uterus were excluded and the surgical indications were to benign uterine diseases. The results obtained by those authors were similar to the present study. Patients mean age was $49.96 \pm 4.8$ years (38 to 68 years), the mean of uterus weight was $427.74 \pm 254.75 \mathrm{~g}$ (150 to $2,000 \mathrm{~g}$ ), the duration of surgery varied from 30 to 140 minutes (mean $61.59 \pm 21.8$ ) and the complication index was $9.8 \%$. No cases of blood transfusion and reoperation were seen. Abdominal hysterectomy was done in $1.9 \%$ of cases due to nonprogression of surgery. VH was possible in $97 \%$ of cases in which the procedure was firstly contraindicated ${ }^{(8)}$.

According to a Cochrane review 2011 and Doganay et al. in 2011, VH has clearly advantageous related to the abdominal and laparoscopic techniques regarding recovery from the surgery, bleeding, urinary route lesions, infections and duration of surgery. So, they 
concluded that this route should be considered the preferable one $e^{(4,9)}$.

A retrospective American study by Tu et al., reported that among 94,599 patients submitted to hysterectomy from 2000 to $2005,78 \%$ of cases were done using the abdominal route. These authors' study compared the abdominal route in a teaching hospital $(82 \%)$ and in a regional hospital $(78 \%)$, showing that vaginal and laparoscopic routes are less taught for students at institutions despite the benefits of these procedure reported in the literature ${ }^{(1)}$.

The number of surgeons able to use the vaginal route has been dropping in the last decades. It is time to return to the use of the vaginal route particularly to distinguish a gynecologist from a general surgeon ${ }^{(7,10)}$. $\mathrm{VH}$ is a safe and simple route. Gynecologist should stimulate the development and the use of the vaginal route in clinical practice: "hysterectomy through a natural orifice" or "hysterectomy without a visible scar". $\mathrm{VH}$ success depends on the indication and appropriate application of the technique ${ }^{(11)}$.

\section{CONCLUSION}

$\mathrm{VH}$ was easily done in most of cases in this study. This technique also had fewer complications intra- and postoperatively, shorter hospital stay and low morbidity. $\mathrm{VH}$ achieved success in almost all cases and no severe complications were observed. We believe that this technique should be more indicated by gynecologists.

\section{REFERENCES}

1. Tu FF, Beaumont JL, Senapati S, Gordon TE. Route of hysterectomy influence and teaching hospital status. Obstet Gynecol. 2009;114(1):73-8.

2. Wu JM, Wechter ME, Geller EJ, Nguyen TV, Visco AG. Hysterectomy rates in the United States, 2003. Obstet Gyencol. 2007;110(5):1091-5.

3. Einarsson Jl, Matteson KA, Schulkin J, Chavan NR, Sangi-Haghpeykar H. Minimally invasive hysterectomies - a survey on attitudes and barriers among practicing gynecologists. J Minim Invasive Gynecol. 2010;17(2):167-75.

4. Nieboer TE, Johnson N, Lethaby A, Tavender E, Curr E, Garry R, et al. Surgical approach to hysterectomy for benign gynaecological disease. Cochrane Database Syst Rev. 2009;(3):CD003677.

5. Moen MD, Noone MB, Elser DM; Urogynecology Network. Natural orifice hysterectomy. Int Urogynecol J Pelvic Floor Dysfunct. 2008;19(9):1189-92.

6. Figueirêdo 0, Figueiredo Netto F. Histerectomia vaginal: novas perspectivas. 2a ed. Londrina: Midiograf; 2007.

7. Salcedo FL. Vaginal hysterectomy in non-prolapsed uteruses: "no scar hysterectomy". Int Urogynecol J Pelvic Floor Dysfunct. 2009;20(9):1009-12.

8. Paparella R, Sizzi O, Rossetti A, De Benedittis F, Paparella R. Vaginal hysterectomy in generally considered contraindications to vaginal surgery. Arch Gynecol Obstet. 2004;270(2):104-9.

9. Doganay M, Yildiz Y, Tonguc E, Var T, Karayalcin R, Eryllmaz OG, et al. Abdominal, vaginal and total laparoscopic hysterectomy: perioperative morbidity. Arch Gynecol Obstet. 2011;284(2):385-9.

10. Obiechina NJ, Ugboaja JO, Onyegbule OA, Eleje GU. Vaginal hysterectomy in a Nigerian tertiary health facility. Niger J Med. 2010;19(3):324-5.

11. Mettler L, Reich H, Feng L, Puntambekar S, Gallinat A, Stark M. Hysterectomy: current methods and alternatives [editorial]. Obstet Gynecol Int. 2010;2010: 705073 . 